\title{
Medical registrar preparation course improves candidate confidence in key aspects of the medical registrar role
}

\author{
Authors: Andrew Redfern, ${ }^{A}$ Mohamed Naeem ${ }^{B}$ and Rakesh Panchal ${ }^{B}$
}

\section{Introduction}

The transition in responsibility from core medical training (CMT) to being a medical registrar can be daunting and many trainees feel unprepared. ${ }^{1,2}$ To tackle this, we piloted a 'Medical Registrar Preparation Course' focused on take management and specific knowledge areas (eg escalation planning), rather than focusing on the more curriculum-driven requirements of the CMT programme.

\section{Methods}

The course involved a generic session given to all core medical trainees on the above topics, followed by small group sessions. Each candidate then spent a day shadowing the acute registrar. They were encouraged to reflect on the experience and were asked to complete a pre- and post-course questionnaire.

\section{Results and discussion}

The course was offered to six senior core medical trainees in respiratory medicine in our hospital. Four took up the offer, of whom one did not complete the shadowing. We achieved confidence improvements in all the taught areas (escalation planning, do not attempt cardio-pulmonary resuscitation, discharging and organ failures), of which four areas reached statistical significance (the rest are likely to have not reached statistical significance owing to the small sample size). The feedback from the trainees was very positive. The specifics of these improvements are seen in Table 1.

\section{Conclusion}

We think this is a basic structure that could be rolled out more widely to support trainees by delivering more focused training prior to their starting in this new role, preferably in the post Annual Review of Competency Progression period prior to the specialty registrar $(\mathrm{SpR})$ transition.

\section{References}

1 Royal College of Physicians. Hospital workforce: fit for the future? London: RCP, 2013. www.rcplondon.ac.uk/guidelines-policy/hospitalworkforce-fit-future [Accessed 5 April 2019].

2 Joint Royal Colleges of Physicians Training Board. Quality criteria for core medical training. London: JRCPTB, 2015. www.jrcptb.org.uk/ cmtquality [Accessed 5 April 2019].

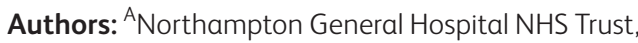
Northampton, UK; ${ }^{B}$ Glenfield Hospital, University Hospitals of Leicester NHS Trust, Leicester, UK

\begin{tabular}{|c|c|c|c|c|}
\hline Questionnaire & $\begin{array}{l}\text { Pre- } \\
\text { course } \\
\text { average } \\
\text { (out of } \\
7 \text { ) }\end{array}$ & $\begin{array}{l}\text { Post- } \\
\text { course } \\
\text { average } \\
\text { (out of } \\
7 \text { ) }\end{array}$ & Difference & $\begin{array}{l}\text { t-test } \\
\text { (p) }\end{array}$ \\
\hline $\begin{array}{l}\text { Confidence in } \\
\text { general for becoming } \\
\text { a medical SpR }\end{array}$ & 2.88 & 5.00 & $2.12+$ & 0.024 \\
\hline $\begin{array}{l}\text { Confidence in } \\
\text { escalation planning } \\
\text { / establishing ceiling } \\
\text { of care }\end{array}$ & 3.75 & 5.75 & $2.00+$ & 0.046 \\
\hline $\begin{array}{l}\text { Confidence in } \\
\text { initiating DNACPR } \\
\text { orders for acutely } \\
\text { unwell patients }\end{array}$ & 4.63 & 5.50 & $0.87+$ & 0.240 \\
\hline $\begin{array}{l}\text { Confidence in } \\
\text { providing advice over } \\
\text { the phone to juniors }\end{array}$ & 4.63 & 5.38 & $0.75+$ & 0.159 \\
\hline $\begin{array}{l}\text { Confidence in } \\
\text { whether to discharge } \\
\text { a patient }\end{array}$ & 3.75 & 6.00 & $2.25+$ & 0.059 \\
\hline $\begin{array}{l}\text { Confidence in } \\
\text { leading a cardiac } \\
\text { arrest }\end{array}$ & 4.25 & 5.25 & $1.00+$ & 0.211 \\
\hline $\begin{array}{l}\text { Confidence in } \\
\text { respiratory failure } \\
\left(\text { eg } \mathrm{PaO}_{2}<8 \text { on } 15 \mathrm{~L}\right. \\
\text { or } \mathrm{T} 2 \mathrm{RF})\end{array}$ & 4.50 & 5.88 & $1.38+$ & 0.005 \\
\hline $\begin{array}{l}\text { Confidence in CVS } \\
\text { failure (eg systolic } \\
\text { BP of } 85 \text { after fluid } \\
\text { resus) }\end{array}$ & 2.75 & 5.75 & $3.00+$ & 0.035 \\
\hline $\begin{array}{l}\text { Confidence in } \\
\text { renal failure (eg an } \\
\text { indication for acute } \\
\text { dialysis) }\end{array}$ & 4.25 & 5.50 & $1.25+$ & 0.071 \\
\hline
\end{tabular}

